\title{
Histone Acetyltransferase KAT2B
}

National Cancer Institute

\section{Source}

National Cancer Institute. Histone Acetyltransferase KAT2B. NCI Thesaurus. Code C17990.

Histone acetyltransferase KAT2B (832 aa, $293 \mathrm{kDa}$ ) is encoded by the human KAT2B gene. This protein is involved in both histone acetylation and transcriptional activation. 